JUVENILE HYPERTHYROIDISM ( $\mathrm{J} \mathrm{H}$ ): THERAPEUTIC 23 OPTIONS ACCORDING TO THE PREDICTION OF THE EVOUTION. Iorcansky, S.; Gruñeiro de Papendieck, L.; Belgorosky, A.; Rivarola, M.A.; Bergada, C. CEDIE-Division Endocrinologia Htal.Ninos "Gutierrez", Bs. As. Argentina.

At present no Laboratory test is available to predict the evolution of $\mathrm{J} \mathrm{H}$ (Craves'disese). A follow up to 2 to $14 \mathrm{y}$. was carried up in 59 patients aged $24 / 12$ to $17 \mathrm{y}$. old ( $\bar{X} \pm$ SD: $9.4 \pm 3.9$ ). They all received antithyroid drugs as initial treatment. Thirty six patients followed for 3 to $14 \mathrm{y}$, , could be reevaluated with $\mathrm{T}_{4}$, T3 and TSH and/or TRH after treatment in at least 2 ocassions? at short-term (ST: 1-2 y. post onset of treatment) and at longterm (LT:more than 3 y.; $\bar{x} \pm 6.23 \pm 3.3$ ). Twenty three patients (64\%) remained hyperthyroid (Hper) between ST and LT and 9(25\%) hypo or euthyroid (Hpo/Eu) between ST and LT; only 4 (11\%) hypo or euthyroid (Hpo/Eu) between ST and LT; only 4 (11\%) changed from Hper at ST to Hpo/Eu at LT. Thus, $89 \%$ did not their thyroid function between ST and LT. The period of the evolution from Hper to Hpo/Eu showed two distinct populations, one
with a $\overline{\mathrm{X}} \pm \mathrm{SD}$ of $17.3 \pm 3.8$ months and another with $\overline{\mathrm{X}} \pm \mathrm{SD}$ of 9.4 $\pm 2.5 \mathrm{y}$. It is concluded that evaluation of thyroid function at ST is useful to predict their status at LT since $90 \%$ of patients showed no variations. Since patients who changed thyroid fuction from Hper to $\mathrm{Hpo/Eu}$ at ST did it in $\overline{\mathrm{X}} 17.3$ months it is advisable to wait up to this time to select another therapeutic options. If Hper persists the possibility of I 131 administration should if Hper persists the possibility of I lal administration sh by the unrelenting course of this disease. WITH RENAL TRASNPLANTATION. Domené,H,M.; Jasper,H.; Ferraris,J.R. División de Endocrinologia, CEDIE, Htal. de Niños"R.Gutierrez" y Sección Nefrologia Pediatrica,Htal.Italiano, Buenos Aires.Argentina. Impaired growth is a major problem in children with renal transplantation (IX). Poor allograft function and corticoesteroids administration have been mentioned as probable caves of dacreased statural growth. The aim of the present study wes: 1) to determine the effect on height velocity (HN) of a reduod methylprechisone (MP) dose and 2) to evaluate growth homone (hah) dyramics by sturying the spantaneaus 24 hars secretion. We sturtied 7 ix patients (chronological 8.6 to 15.2 years), with senm creatinine from 0.5 to 0. ang/ $\mathrm{dl}$, reciving $\mathrm{MP}$ at a doees of $0.23 \pm 0.02 \mathrm{mg} / \mathrm{kg} / \mathrm{dey}(x \pm \mathrm{sd})$ with a previaus $\mathrm{HN}$ of $2.58 \pm 1.14 \mathrm{~d} / \mathrm{yr}$. After one year with a lower MP dome $(0,17 \pm 0,01 \mathrm{mg} / \mathrm{kg} /$ day), $H N$ was $3.42 \pm 1.94 \mathrm{om} / \mathrm{yr}$. $(n=7)$ and $2.30 \pm 1.03 \mathrm{~cm} / \mathrm{yr}$. in 4 patients who remined preptertal during that year. In these 4 patients mean haH conoentration wes $2.59 \pm 0.98 \mathrm{ng} / \mathrm{ml}$, no different from a normal ontrol grap: $2.78 \pm 0.76 \mathrm{ng} / \mathrm{ml}(\mathrm{n}=3)$ Not $\mathrm{haH}$ pecks $>5 \mathrm{ng} / \mathrm{ml}$ were detected in 2 of these patients, while momal controls showed 1 to 4 peds. In conclusion a lower MP doee cid not improve $H$ in prepubertal patients with $B \times$ and docreased growth could be related, in some dhildren, to an impaired haH socretion.
LACK OF CORRELATION OF TOTAL ESTRADIOL (TO E2) AND 26 NON-SHBG-BOUND E2 (nOn-SHBG-b E2)WITH GROWTH VEIOCTYY DURING PUBERTY IN NORMAL BOYS. Belgorosky, A, ;Martínez A. ;Escobar,M.E.;Heinrich, J.J.;Rivarola,M.A. CEDIE. Hospital de Niños, Buenos Aires, Argentina.

Recent evidence suggests that normal growth during male puberty depends on the combined effect of testosterone( $T$ ) and growth hormone while the role of estrogens, if any, has not been established. Correlations between growth velocity $(\mathrm{GN})$ and senm totalT $\mathrm{T}(\mathrm{T} \mathrm{O} \mathrm{T})$, non-FEG-b T, To E2 or non SFBC-b E2 wes made in 16 normal boys (mean $\pm S D$ chronological age, $14.1 \pm 1.4$, mean $\pm S D$ bone age $12.3 \pm 1.64$ years) in Tarner's stages II-IV of genital development. GN was evaluated in a 6-menths-period but growth was followed ip for at least 1 year. None of the subjects had overocme their peak height velocity as julped by 3 onseartive measumements. T and F2 non-SBG-b fractions were caloulated by a mathematical model basod on the law of mass action. Mean $\pm S D$ To $T$ and non $\$ E G-b$ T were $222 \pm 48$ and $75 \pm 22 \mathrm{ng} / \mathrm{dl}$ respectively while To $\mathrm{E} 2$ and non $\mathrm{FEC}-\mathrm{b}$ E2 were $18.1 \pm 4.4$ and $9.07 \pm 2.88 \mathrm{pg} / \mathrm{ml}$ respectively. To $T$ and mon SHEG-b T stowed a highly significant correlation with GV $(p<0.01)$ while $n$ significant correlation wes fand between To $E 2$ or nonSHG-b E2 and GV. These studies supgest that senm E2 dbes not play a role in the pubertal growth spurt of boys.

\section{MAMMARY GLAND DEVELOPMENT UNDER THE EFFECT OF A}

27 PLACENTAL PROTEIN. Calaff,G.;Capurro,M.T.;Beas, $F$. Universidad Metropolitana de Cs.de la Educación. Centro de Investigaciones Matemo Infantil, Hospital Paula Jaraquemada, Facultad Medicina, Universidad de Chile, Santiago, Chile.

A protein from human placenta, the Uterotrophic Placental Protein (UTPH) was isolated in our lab(Beas \& Flores, 1969). It evoked crop sac stimulation in pigeons, inhibited mammary growth produced by estradiol (E) and progesterone (P) in ovariectomized rats and increased DNA synthesis in 5 day organ cultures of mouse mermary gland. The objective of this work was to analyze the effect of UTPH on mammary gland development in intact virgin Balb/c mice injected during 8 days. There were four experimental groups: (I) Control: $0.3 \mathrm{ml}$ saline sol., (II) $\mathrm{E}+\mathrm{P}: 0.4 \mathrm{ug} / 0.3 \mathrm{ml}$ and $0.8 \mathrm{mg} /$ $0.3 \mathrm{ml}$ respectively, (III) $\mathrm{E}+\mathrm{P}+\mathrm{UTPH}: 200 \mathrm{ug} / 0.3 \mathrm{ml}$ and (IV) UTPH. Results on who lemount mammary gland indicated that there was: a) not significant difference among groups vs control in the number of marmary gland ducts. b) a significant increase in number of terminal end buds (TEB) in group II vs I $(p<0.0005)$ and III $(p<0.0005)$ or II vs IV $(p<0.0005)$. c) a significant increase in number of alveoli of group II $(p<0.0005)$ and III $(p<0.0005)$ vs control. We can conclude from these studies that UTPH inhibited $E+P$ action on TEB development while had no effect on ducts and alveoli.

PULMONARY FINDINGS IN POSTMORTEM EXAMINATIONS OF

28 PEDIATRIC ACQUIRED IMMUNODEFICIENCY SYNDROME (AIDS). Adams, J.A.;Birriel, J.A.;Saldana, M.J.;Vemon, D. Department of Pediatrics, University of Miami School of Medicine, Miami, Fl., U.S.A.

A retrospective study of autopsies of children with the diagnosis of AIDS was done. From March 1983 to September 1986 a total of 24 autopsies were done in children with AIDS at the University of Miami/Jackson Memorial Hospital. Twenty three cases were revieved as to the pulmonary pathology. In 21 cases the primary cause of ceath wes pulmonary. Of these, $12(5 \%)$ had a Gram negative $(\mathrm{G}-)$ becterial pathogen alone or in combination with Immhoid Intersticial Prammitis (LIP) or Phamoystis carinii (PCP). Of the 2l cases 8 (3\%\%) had LIP. Four of the 8 also had G- pnamonia (Psaudomones auriginosa, E.coli). One case of LIP with Staptrlooocus araus pnamonia, 2 coses of LIP and Cytomegalovinus (ON), and one case of LIP and PCP. The histological changes of diffluse alvealar change and barotrama correlate well clinically with the nuber of days on ventilatory support, and aygen consentration utilized. None of the patients expired as a consequenoe of LIP alone, Or data indicates: \# 1 Multiple pathogens appear to play an important role in end stage respiratory failure in these children. \# 2 LIP alcre does not appear to be a cave of end stace respiratory failure, however, LIP alone with either viral or kecterial pathogens acoant for $3 \%$ of the pulmonary pathologic diagnosis. \# $3 \mathrm{G}-$ Bacterial pathogens play an important role in end stage respiratory failure in Allos. \#4 The use of systemic steroids for the treatment of LIP in end stage, would be contraindicated in light of the mixed pulmenary pethogens. 